\title{
Seismo-Structural Interpretation and Petrophysical Evaluation of Ugwu-Field, Coastal Swamp Depositional Belt of the Niger Delta Basin
}

\author{
${ }^{1}$ UGWU, EB; ${ }^{1}$ UGWU, SA; ${ }^{1}$ UGWUEZE, CU; ${ }^{11}$ EZE, SU; ${ }^{2}$ BELLO, MA \\ ${ }^{*}$ Department of Geology, University of Port Harcourt, Port Harcourt, Nigeria \\ ${ }^{2}$ Department of Petroleum Engineering and Geosciences, Petroleum Training Institute, Effurun, Nigeria. \\ *Corresponding Author Email: uchechukwueze2014@gmail.com
}

\begin{abstract}
Structural interpretation of 3-D seismic data and well log have been applied to unravel hydrocarbon entrapment pattern and petrophysical parameters of X-field within the coastal swamp region of the Niger Delta.. Four reservoir intervals (A, B, C and D) delineated as (W-026, 032, 042 and 048) using gamma ray and resistivity log response. Structural interpretation for inline 5158 revealed four horizons (A, B, C and D) and eight (8) faults labelled (F1, F2, F12, F13, F21, F22, F23, and F24) were mapped. It was observed that the hanging wall block due to reverse drag or rollover anticline slided over fault F12 and created fault F2, thereby creating subsidence where sediments can be deposited. Therefore, faults F2 and F12 created rollover structures which cuts across the entire four reservoirs and invaluably responsible for trapping of hydrocarbon in the field. RMS map developed for horizons ' $A$ ' and 'B' revealed high amplitude anomalies, while variance attribute for both horizons showed relatively uniform lithology observed from east to west across the study area. While from north-east to south west, variance was observed to increase relatively which indicates different lithology. These trend exposes dipping of the channel fill at both flanks by creating extensive faulting. Results of petrophysical evaluation for reservoirs ' $\mathrm{A}$ ' and ' $\mathrm{B}$ ' across the four wells were analyzed. For reservoir ' $\mathrm{A}$ ', porosity values of $32.8 \%, 24.8 \%, 25.9 \%$ and $27.1 \%$ were obtained for wells $\mathrm{W}-048,042,026$ and 032 respectively with an average of $27.65 \%$, while for reservoir ' $\mathrm{B}$ ' porosity values of $26.83 \%, 26.93 \%, 25.59 \%$ and $27.99 \%$ for wells $\mathrm{W}-048,042,026$ and 032 were obtained respectively with an average of $26.84 \%$. This porosity values were rated very good to excellent for reservoir 'A' and very good for reservoir 'B', while Permeability values of the order $(\mathrm{K}>1000 \mathrm{mD})$ were obtained for both reservoirs across the four wells and is rated excellent. Hydrocarbon saturation $\left(\mathrm{S}_{\mathrm{hc}}\right)$ across the four wells averages at $68.57 \%$ for reservoir ' $\mathrm{A}$ ' and $68.67 \%$ for reservoir ' $\mathrm{B}$ ' which is high. Log motifs using gamma ray log for well-026 was integrated with seismic facies to infer on depositional environment of the reservoirs horizons showed a combination of serrated funnel/blocky shape log response and coarsening upward cycles. For reservoirs 'A', 'B' and ' $\mathrm{C}$ ' the log shape pattern indicates deposition in a fluvial / tidal, channel environment while for reservoir ' $\mathrm{D}$ ' the pattern indicates deposition in deltaic front environment. Isochore maps computed for horizons ' $\mathrm{A}$ ' and ' $\mathrm{B}$ ', shows that horizon ' $\mathrm{A}$ ' is relatively thick and this pattern suggests increased tectonic activities during deposition of reservoir ' $\mathrm{A}$ ' and is an indication that reservoir ' $\mathrm{A}$ ' is a synrift deposit.
\end{abstract}

DOI: https://dx.doi.org/10.4314/jasem.v24i9.16

Copyright: Copyright (C) 2020 Ugwu et al. This is an open access article distributed under the Creative Commons Attribution License (CCL), which permits unrestricted use, distribution, and reproduction in any medium, provided the original work is properly cited.

Dates: Received: 10 August 2020; Revised: 16 September 2020; Accepted: 22 September 2020

Keywords: 3-D Seismic interpretation, Faults, Seismostratigraphy, Well log, Seismic Attributes, Petrophysical parameters.

INTRODUCTION: The integration of 3D seismic data and well $\log$ have proved valuable in the interpretation of subsurface structures suitable for hydrocarbon accumulation. Most interpreters recognize that integration of seismic data with other data types are required to properly interpret a 3D seismic data (Hart et al., 1997). The seismic reflection method ever since its discovery in the late $1920 \mathrm{~s}$, has and still remains one of the most effective tools in the search for hydrocarbons. Reflections are due to contrast in acoustic impedance in the subsurface caused by difference in physical properties of rocks which can be density and compressional wave velocity and can be explained in terms of lithology, porosity and porefill (Karbalaali et al., 2013; Hansen et al., 2008; and Ukaigwe, 2000; as cited by Eze et al., 2019). Meanwhile, the principal objective of a 3D seismic survey is to delineate structures, exact definition of subsurface stratigraphy and rock physical properties. Many structures that provide excellent traps do not contain oil and gas in economic quantities (Telford et al., 1976). And due to the high cost of drilling, effort is made to derive from the seismic data as much information as possible about the nature of the rocks and subsurface structures in an effort to form an opinion about the probability of encountering petroleum in the structures delineated from the seismic record. Reflections are usually identified with bedding planes based on correlations with observations in boreholes, velocity information, synthetic seismograms or previous history of the area (Telford et al., 1976). A three-dimensional picture of the subsurface and its interpretation is necessary to determine whether closure exists, the area within the closing contour and location of the highest point on the structures. Faults that have been identified on the seismic records or cross sections are drawn on a map and depth values determined. Well logs provide information on the nature of the strata penetrated, physical properties of the rocks, depths at which these 
rocks are encountered and porosity and permeability of the rock units etc. Well logs provide a vertical resolution much greater than that obtainable with seismic data (Asquith and Daniel, 2003). It can resolve features that are decimeters thick (or less), whereas seismic data, can only resolve features not lesser than the turning thickness (which could be few tens of meters thick). Furthermore, log shapes (particularly the Gamma ray and Resistivity) can be used to identify depositional features (channels, parasequences, e.t.c) that may be poorly resolved from seismic data (Etu-Efeotor, 1997). Some reaserchers such as Adeoti et al., (2014); Ajisafe and Ako, (2013); Alao et al., (2013); Ayolabi and Adigun, (2013); and Opara, (2010) have integrated well log and seismic data to characterise reservoirs in various onshore and offshore Niger Delta fields. They observed complex pattern of subsurface structures bounded by growth fault, faulted rollover anticlines and collapsed crest structures. They also discovered that a system of antithetic and synthetic normal faulting compartmentalized the reservoirs into several blocks of variable sizes. This study aims to intergrate results from seismic section interpretation and well $\log$ to delineation of structural styles and mechnism for hydrocarbon accumulation and petrophysical estimation within the interpreted reservoir horizons.

Geologic Setting: The study area falls within OML 23, operated by Shell Petroleum Development Company (SPDC) of Nigeria and lies between latitudes $4^{0} 37^{\prime} 36^{\prime \prime} \mathrm{N}$ and $4^{0} 40^{\prime} 00^{\prime \prime} \mathrm{N}$, and longitudes $6^{0} 35^{\prime} \mathrm{E}$ and $6^{0} 40^{\prime} \mathrm{E}$; within the Niger Delta.

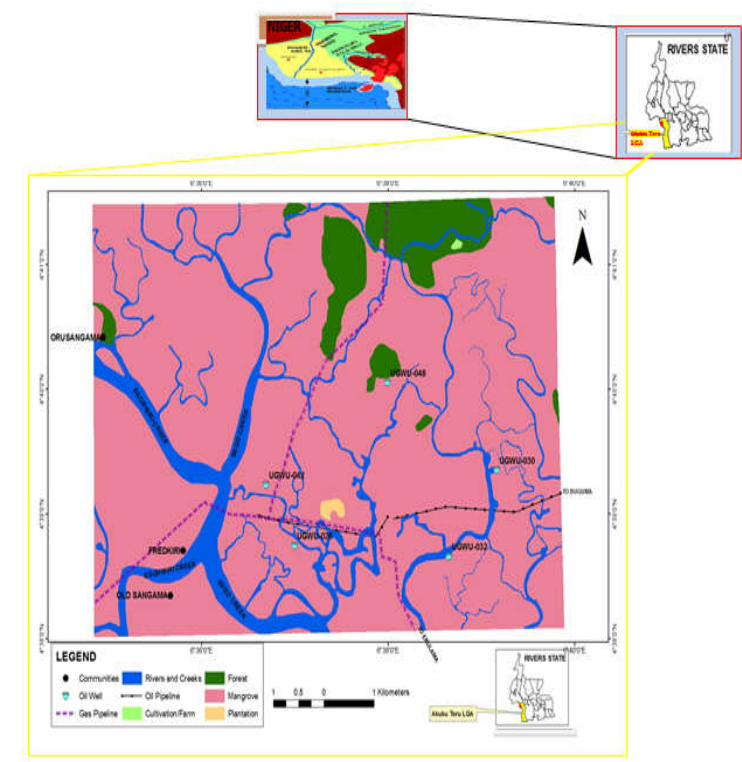

Fig 1: Base map of study area showing Ugwu-field and the oil well locations (Ugwu-026, 032, 042, and 048).

\section{MATERIALS AND METHODS}

Materials: In this study, a suite of composite logs which contains Gamma ray (GR), Resistivity, Spontaneous Potential (SP), Sonic, density, and Neutron logs from four wells was used. The respective depths of the wells are 11592.02ft for 'Well-026'; 10718.52ft for 'Well-032'; 13310.53ft for 'Well-042', which is the deepest and $11488.02 \mathrm{ft}$ for 'Well-048'. Also a 3D seismic volume (in SEG-Y format) having a total of 1106 inlines and 791 cross lines was used for this study. The dataset was provided by Shell Petroleum Development Company (SPDC) Port Harcourt.

Picking of reservoir intervals, Well correction and Well-to-seismic correlation: The first step in this study was to pick the reservoir intervals from well logs. The reservoir intervals were picked using a combination of gamma ray and resistivity log signatures across the four wells. Lithologic units were delineated in vertical succession by distinct surfaces which represent changes in lithologic character. Four reservoir intervals (marked A, B, C and D) were picked. Well correlation which is the determination of the continuity and equivalence of lithologic units particularly reservoir sands or marker sealing shales across a region of the subsurface was carried out across the wells in the field. This includes the recognition of $\log$ pattern (sand and shale signatures) on well logs and matching subsequently these patterns from one well to the other. This provided the basis for correlation to determine the lateral extent of the reservoir sand of interest and determination of the resistivity of the interpreted formations from the resistivity curves. Accurate correlations of well logs is very important for reliable geologic interpretations (Etu-Efeotor, 1997), as it provides information such as lithology, reservoir thickness, tops and bases of formations (Tearpock and Bishke, 2003). Well-to-seismic tie seeks to import wells information into the seismic. Chechshot data from well-026 was used. The acoustic velocities from sonic log was multiplied with density log from well026 to compute new acoustic impedance (AI) log. This impedance $\log$ was converted to reflectivity, which was then converted from depth to time using an appropriate wavelet to produce a synthetic seismogram for well-026.

Fault / Horizon Mapping, Picking of major faults and creation of surface, depth and attribute Maps: Fault mapping was done by picking fault segments on vertical seismic sections and correlating them across from line to line (Peter and Amandeep 2013). Faults were identified on inline (dip lines) 5158 of the seismic section by selecting points where the seismic events are truncated or at points of discontinuity. Following

$U G W U, E B ; U G W U, S A ; U G W U E Z E, C U$; EZE, SU; BELLO, MA 
this, four horizons (A, B, C and D) were picked at different two way time's. Horizon ' $A$ ' was picked at two way time of $-2227.76 \mathrm{~ms}$, cuts the following faults (F2, F12, and F24). Horizon 'B' was picked at TWT of $-2475.09 \mathrm{~ms}$, cuts the following faults (F21, F2, and F22). Horizon ' $C$ ', picked at TWT $-2516.98 \mathrm{~ms}$, cuts the following faults (F21, F2, and F22), while horizon 'D', picked at TWT of $-2697.25 \mathrm{~ms}$, cuts the following faults (F23, F21, and F2). Fault (F2) was observed to cut across the entire four horizons, hence was considered the major fault which cuts across the studied horizons. Time structural maps were produced for horizons 'A \& B'; by plotting reflection times observed on inline 5158 for these horizons against shot point position on a map. However, since subsurface structures occur at depths, the time horizons maps were converted to depth to produce depth contour maps. In depth conversion, we make use of average velocity from the surface to our horizon of interest or the interval velocities within each layer from the surface down to our target horizon. Fault visualization on $3 \mathrm{D}$ seismic volumes is enhanced by computing edge detection attributes map (Bahorich and Farmer, 1995). RMS (root mean square) and variance attributes, measures vertical and lateral changes in the seismic response respectively, caused by changes in acoustic impedance. Therefore in this study, RMS and variance attribute maps were computed for horizons 'A \& B'.

Petrophysical evaluation: Petrophysical evaluation provides an understanding of the rock and fluid properties within the reservoir rocks. These properties form the basis for detailed reservoir quality evaluation. Five petrophysical parameters which includes Volume of shale $\left(\mathrm{V}_{\text {shale }}\right)$, porosity $(\Phi)$, water saturation $(\mathrm{Sw})$, hydrocarbon saturation (Sh) and permeability index (k) were computed for the top and base of reservoirs A and $\mathrm{B}$.

Volume of Shale was obtained for the four wells using Larionov tertiary rock method (Larionov 1969; and Sanuade et al., 2018); given as

$$
\begin{aligned}
& \left(\mathrm{V}_{\text {sh }}\right)=0.083\left(2^{3.7^{*} \mathrm{IGR}}-1\right) \\
& \mathrm{GR}_{\text {index }}=\frac{\text { GR-GRmin }}{\text { GRmax }- \text { GRmin }}
\end{aligned}
$$

Where; $\mathrm{GR}_{\text {index }}=$ gamma ray index, $\mathrm{GR}_{\log }=\mathrm{GR}$ reading of formation, $\mathrm{GR}_{\min }=$ minimum $\mathrm{GR}$ for (clean sand), $\mathrm{GR}_{\max }=$ maximum GR for (shale).

Porosity was calculated for the four wells from bulk density log using: $\phi($ Den $)=\frac{\rho_{m a}-\rho_{b}}{\rho_{m a}-\rho_{f l}}$

Where; $\phi_{\text {Den }}=$ density derived Porosity, $\rho_{\mathrm{ma}}=$ Matrix density usually $2.65 \mathrm{~g} / \mathrm{cm}^{3}$ for sandstones, $\rho_{\mathrm{b}}=$ bulk density of formation, $\rho_{\mathrm{fl}}=$ Fluid density usually 0.9

By Using the log reading obtained from the given logs for the four wells, the porosity of each reservoir interval were determined and an average value obtained.

Water saturation ( $\mathrm{Sw}$ ) was determined using the Archie (1942) model (for clean sand formations) given by:

$$
S_{w}=\left(\frac{a R_{w}}{\emptyset^{m} R t}\right)^{1 / n}
$$

Where; $S_{w}=$ water saturation of un-invaded zone, $R_{w}=$ Formation water resistivity, $\mathrm{R}_{\mathrm{t}}=$ formation Resistivity (Un-invaded zone), $\phi=$ Porosity, a $=$ Tortousity factor $\mathrm{m}=$ Cementation exponent, $\mathrm{n}=$ Saturation exponent

Hydrocarbon saturation $\left(\mathrm{S}_{\mathrm{h}}\right)$ was comouted using

$\mathrm{S}_{\mathrm{h}}=\left(1-\mathrm{S}_{\mathrm{w}}\right)$

Permeability index (k) in millidarcy was calculated using Owolabi and Obot (2001) model. The model is given as:

$K=307+26,552 \emptyset^{2}-34540(\varnothing *$

$\left.S_{w i}\right)^{2}$ for oil - sand

Where; $\phi=$ porosity, $\mathrm{S}_{\mathrm{wi}}=$ irreducible water saturation given as

$\mathrm{S}_{\mathrm{wi}}=(\mathrm{F} / 2000)^{1 / 2}$

$\mathrm{F}$ is the formation factor $(\mathrm{F})$ given as

$\mathrm{F}=\mathrm{a} / \phi^{\mathrm{m}}$

Where; $\mathrm{a}=$ tortuosity factor $=0.62, \mathrm{~m}=$ cementation factor $=2.15$. The average values of the petrophysical parameters within the reservoir intervals from the four wells were obtained. Porosity and permeability values obtained were rated based on Rider (1996) qualitative evaluation criteria shown in Table 1.

\section{RESULTS AND DISCUSSION}

Figure 2 shows the reservoir intervals (A, B, C and D) at top and base delineated for the four wells, which were correlated to determine the lateral extent of the reservoir sand across the wells in the field. It was also observed that structural dip increased downward and 
decreases upward (extensive faulting was observed within the Agbada formation). This was so because faults and other structures tend to decrease upward (Benin formation) towards the surface (Etu-Efeotor, 1997).

Table 1: Qualitative Evaluation of Porosity and permeability

\begin{tabular}{ll}
\multicolumn{2}{c}{ (After Rider, 1996) } \\
\hline $\begin{array}{l}\text { Percentage Porosity } \\
(\%)\end{array}$ & $\begin{array}{l}\text { Qualitative } \\
\text { Description }\end{array}$ \\
\hline $0-5$ & Negligible \\
$5-10$ & Poor \\
$11-15$ & Fair \\
$15-20$ & Good \\
$20-30$ & Very Good \\
$>30$ & Excellent \\
& \\
\hline Average Permeability & Qualitative \\
Value (md) & Description \\
\hline$<10.5$ & Poor \\
$11-15$ & Fair \\
$15-50$ & Moderate \\
$50-250$ & Good \\
$250-1000$ & Very Good \\
$>1000$ & Excellent \\
\hline
\end{tabular}

Figure 3 shows result of well-to-seismic correlation using a synthetic seismogram, with well-026 as control well. The respective tops and bases of horizons A, B, $\mathrm{C}$ and $\mathrm{D}$, were picked on inline 5158 of the seismic section as shown in Figure 4. Eight (8) faults were interpreted on inline 5158 and labelled as (F1, F2, F12, F13, F21, F22, F23, F24) in Figure 4. Table 2 shows the faults and horizons which each fault cuts at their respective two-way-time on inline 5158 of the seismic section.

In Figure 4, it was observed that the hanging wall block due to reverse drag or rollover anticline slided over fault F12, creating another fault F2, thereby creating subsidence where sediments can be deposited.

Therefore, faults F2 and F12 create a rollover anticline which cut across the entire four reservoirs and invaluably responsible for trapping of hydrocarbon in the field. Also, it was observed that fault F24 cut across horizon ' $A$ ' while fault F21 cut across horizons 'B', ' $C$ ' and 'D'. Fault F23 cuts only horizon D, while fault F22 cuts horizon 'B', 'C', 'D' respectively.

Table 2: INLINE 5158; Showing identified two way time within the mapped horizons

\begin{tabular}{|c|c|c|c|c|c|}
\hline S/ & & & TUT & & \\
\hline $\mathrm{n}$ & ts & )ms & ms & $\mathrm{ms}$ & ms \\
\hline 1 & F2 & -2350 & -2600 & -2650 & -2795 \\
\hline 2 & F12 & -2400 & - & - & - \\
\hline 3 & F24 & -2227 & - & - & - \\
\hline \multirow[t]{3}{*}{4} & F21 & - & -2475 & -2500 & -2800 \\
\hline & F22 & - & -2750 & -2800 & - \\
\hline & F23 & - & - & - & -2850 \\
\hline
\end{tabular}

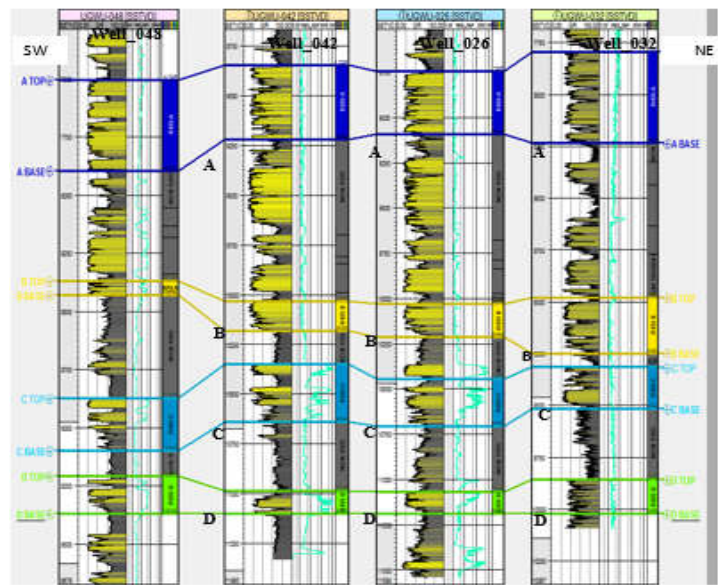

Fig 2: Well correlation for the four wells, showing the top and base of the reservoir intervals (A, B, C and D) delineated for each well.

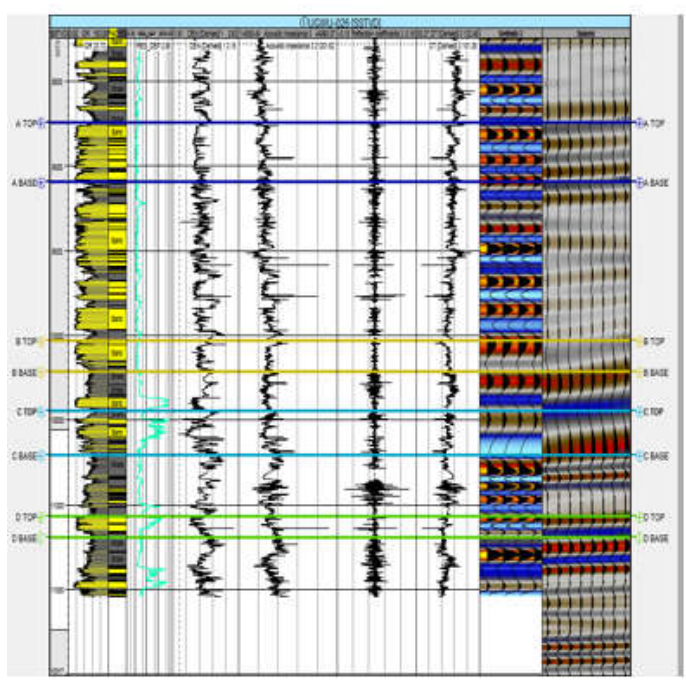

Fig 3: Seismic-to-well tie using synthetic seismogram

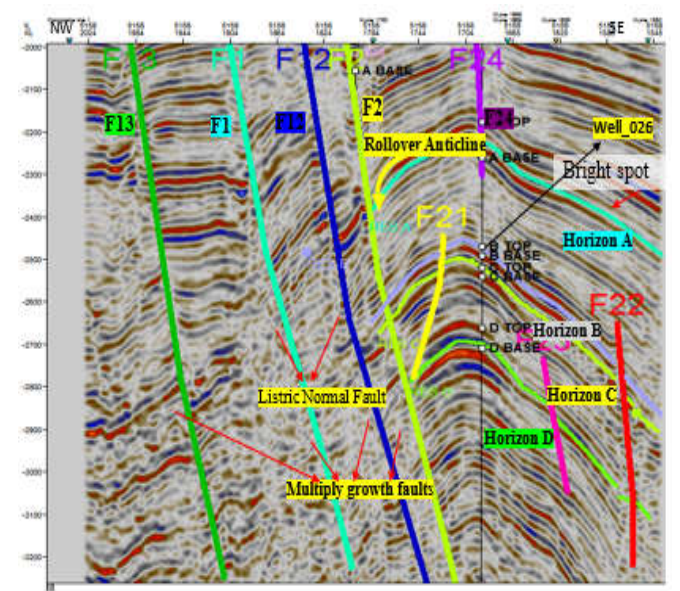

Fig 4: Seismic section for Inline 5158 showing top and base of mapped horizons and faults. Well-026 is the control well. 


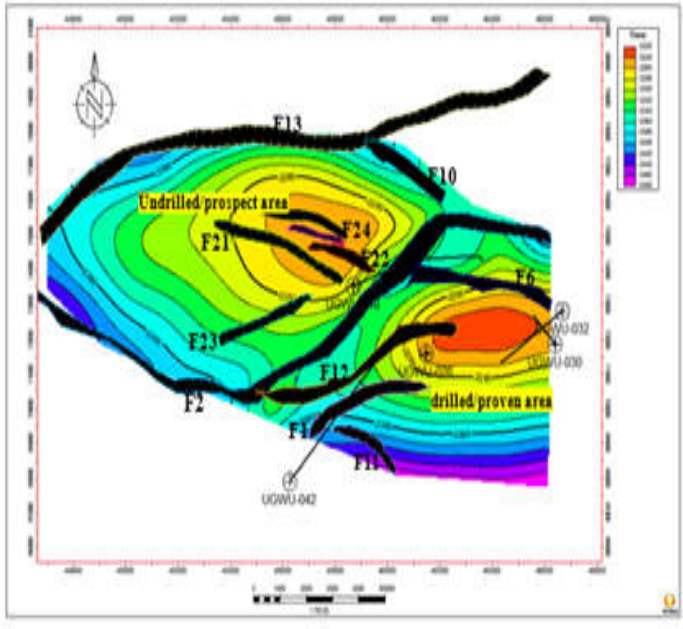

Fig 5a : Time map of horizon ' $\mathrm{A}$ ' view on (E-W direction)

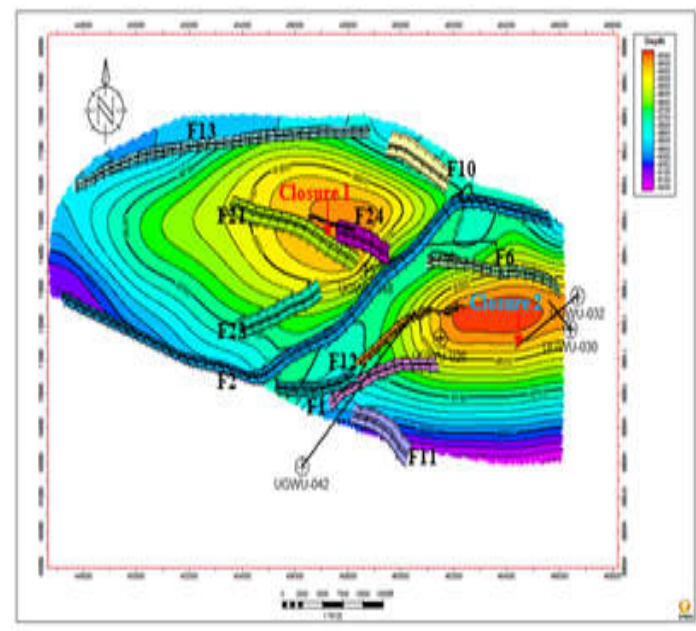

Fig 5b : Depth map of horizon 'A' view on (E-W direction)

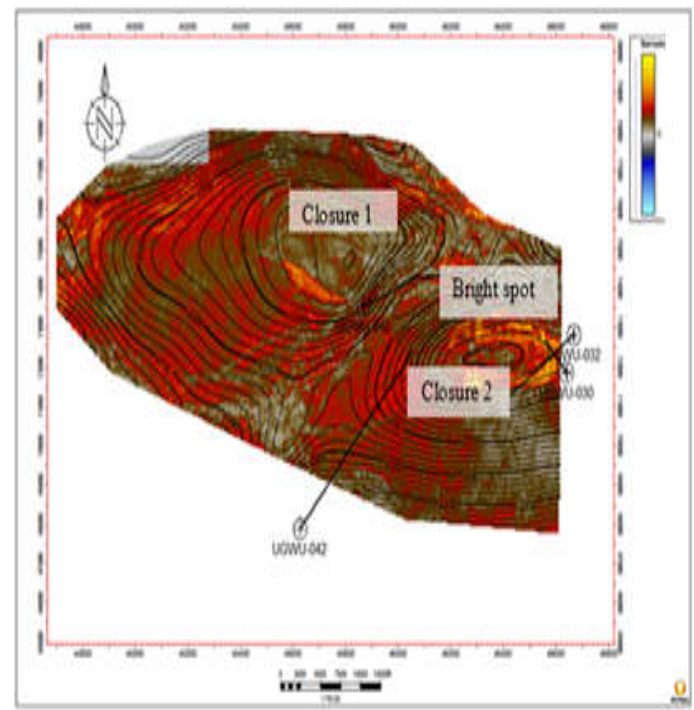

Fig 5c: RMS map of horizon 'A' view on (E-W direction)

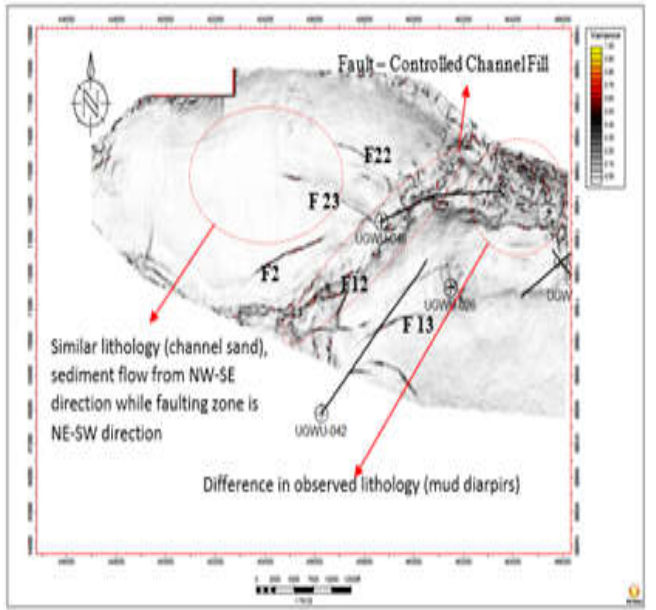

Fig 5d: Variance map of horizon 'A' view on (E-W direction)

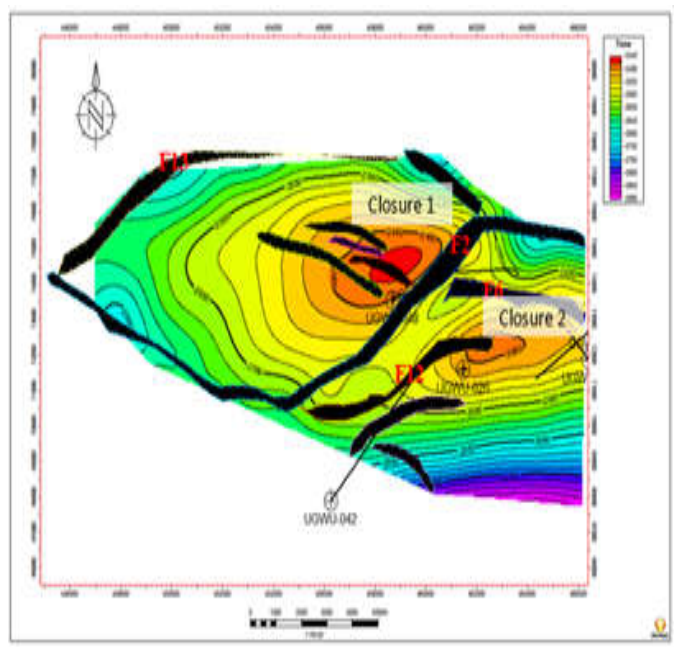

Fig 6a: Time map of horizon 'B' view on (E-W direction)

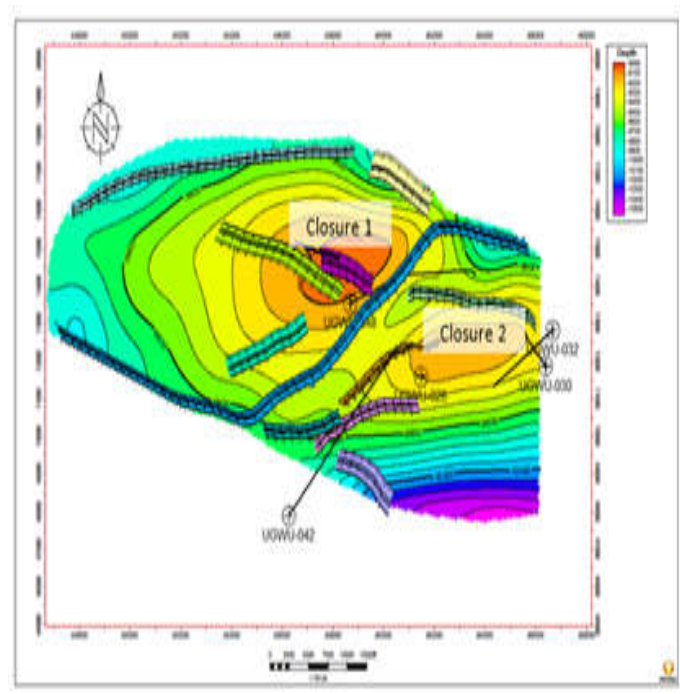

Fig 6b: Depth map of horizon 'B' view on (E-W direction)

$U G W U, E B ; U G W U, S A ; U G W U E Z E, C U ; E Z E, S U ; B E L L O, M A$ 


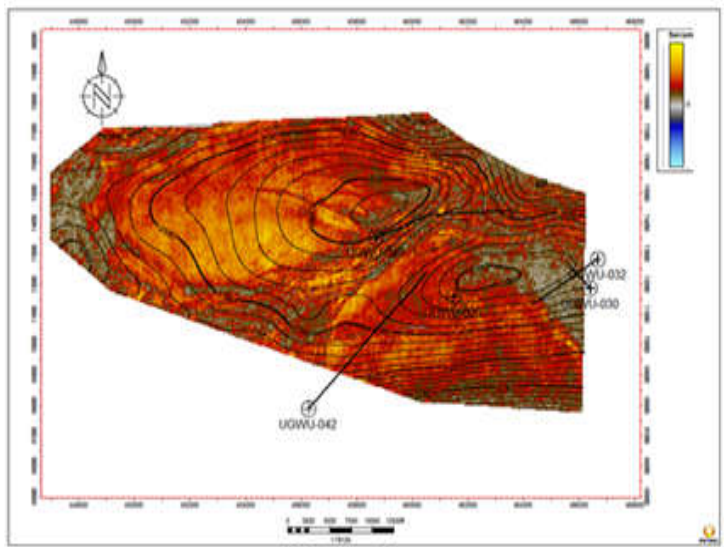

Fig 6c: RMS map of horizon 'B' view on (E-W direction)

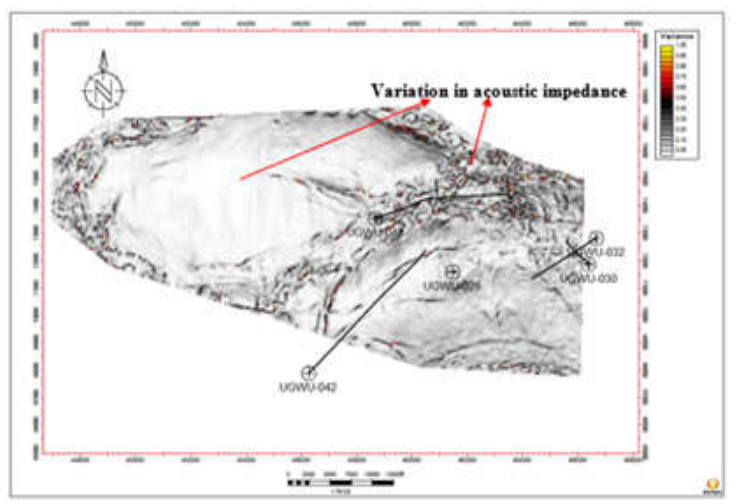

Fig 6d: Variance map of Horizon 'B' view on (E-W direction)
The shallowest and deepest parts of the surface of horizon ' $\mathrm{A}$ ' and ' $\mathrm{B}$ ' were estimated to occur at a two way time of $-2280 \mathrm{~ms}$ and $-2380 \mathrm{~ms}$ for horizon ' $A$ ' and two way time of $-2480 \mathrm{~ms}$ and $-2580 \mathrm{~ms}$ for horizon ' $\mathrm{B}$ ' on their time contour maps (Figures $5 \mathrm{a}$ and $6 \mathrm{a}$ ). For horizon ' $A$ ', these times corresponds to depths of about $8500 \mathrm{ft}$ and $8700 \mathrm{ft}$ respectively on the depth contour map for horizon ' $A$ ' (Figure $5 b$ ). For horizon 'B', it corresponded to depths of $-9100 \mathrm{ft}$ and $-9600 \mathrm{ft}$ on the depth contour map for horizon 'B' (Figure 6b). The depth maps for horizons ' $A$ ' and ' $\mathrm{B}$ ' (Figures $5 \mathrm{~b}$ and $6 \mathrm{~b}$ ) showed the structural high closures 1 and 2 against fault which is a possible prospect area. Also, from root mean square (RMS) map developed for horizon ' $A$ ' and ' $B$ ' (Figures $5 \mathrm{c}$ and $6 \mathrm{c}$ ), it was observed that the closures seen on the depth maps for both horizons, showed high amplitude anomalies (bright spot) (in Figures 5c and 6c). However, the top of closure 1 on the RMS map in figure $5 \mathrm{c}$ was observed to have a low amplitude value on the scale and maybe due to faults mapped which act as a sealing fault on the reservoir. Channels-like structures and faults are more visible on variance maps (fault delineating seismic attribute) shown in Figures $5 \mathrm{~d}$ and $6 \mathrm{~d}$. From the legend on the variance maps, it was observed that there was relatively uniform lithology observed from east to west across the study area. While from north-east to south west direction, variance was observed to increase relatively which indicates different lithologies.

\begin{tabular}{|c|c|c|c|c|c|c|}
\hline \multirow[t]{5}{*}{ Reservoir } & Parameters & Well-048 & Well-042 & Well-026 & Well-032 & Average \\
\hline & Base(ft) & 7878.01 & 9225.41 & 9125.32 & 8224.53 & 8613.32 \\
\hline & $\operatorname{Top}(\mathrm{ft})$ & 7500.02 & 8875.42 & 8750.43 & 7800.32 & 8231.04 \\
\hline & Gross Thickness(ft) & 378.43 & 350.23 & 374.52 & 424.53 & 382.43 \\
\hline & $\mathrm{V}_{\mathrm{sh}}(\%)$ & 8.9 & 9.4 & 7.79 & 13 & 9.77 \\
\hline \multirow[t]{7}{*}{$\mathbf{A}$} & Net Thickness(ft) & 369.32 & 341.42 & 367.31 & 412.23 & 372.31 \\
\hline & Net/Gross & 0.976 & 0.974 & 0.979 & 0.969 & 0.975 \\
\hline & $\Phi(\%)$ & 32.8 & 24.8 & 25.9 & 27.1 & 27.65 \\
\hline & $\mathrm{K}(\mathrm{mD})$ & 2700.75 & 1666.98 & 1785.66 & 1899.95 & 2013.34 \\
\hline & $\mathrm{S}_{\mathrm{w}}(\%)$ & 25.53 & 34.51 & 33.43 & 30.34 & 31.43 \\
\hline & $\mathrm{S}_{\mathrm{wrr}}(\%)$ & 6.5 & 8.5 & 8.2 & 7.5 & 7.7 \\
\hline & $\mathrm{Sh}(\%)=1-\mathrm{Sw}$ & 74 & 65 & 67 & 70 & 68.57 \\
\hline \multirow{6}{*}{ Reservoir } & Parameters & & & & & \\
\hline & Parameters & Well-048 & Well-042 & Well-026 & Well-032 & Average \\
\hline & Base(ft) & 8424.53 & 10187.64 & 10200.12 & 9250.43 & 9515.54 \\
\hline & Top(ft) & 8375.22 & 10037.31 & 10024.52 & 8975.32 & 9353.31 \\
\hline & Gross Thickness(ft) & 50.34 & 150.62 & 175.23 & 274.53 & 163.32 \\
\hline & $\mathrm{V}_{\mathrm{sh}}(\%)$ & 1.23 & 7.1 & 6.78 & 9.79 & 6.23 \\
\hline \multirow[t]{7}{*}{ B } & Net Thickness(ft) & 48.9 & 144.22 & 167.53 & 265.21 & 157.31 \\
\hline & Net/Gross & 0.980 & 0.954 & 0.960 & 0.964 & 0.965 \\
\hline & $\Phi(\%)$ & 26.83 & 26.93 & 25.59 & 27.99 & 26.84 \\
\hline & $\mathrm{K}(\mathrm{mD})$ & 1923.42 & 1875.39 & 1723.48 & 2031.47 & 1888.44 \\
\hline & $\mathrm{S}_{\mathrm{w}}(\%)$ & 32.69 & 31.08 & 32.75 & 28.8 & 31.33 \\
\hline & $\mathrm{S}_{\mathrm{wrr}}(\%)$ & 8 & 7.6 & 8 & 7.8 & 7.9 \\
\hline & $\mathrm{Sh}(\%)=1-\mathrm{Sw}$ & 67.31 & 68.92 & 67.25 & 68.92 & 68.67 \\
\hline
\end{tabular}

UGWU, EB; UGWU, SA; UGWUEZE, CU; EZE, SU; BELLO, MA 
These trend exposes dipping of the channel fill at both flanks by creating extensive faulting which is shown in Figures $5 \mathrm{~d}$ and $6 \mathrm{~d}$. Results of average petrophysical parameters computed for reservoir ' $A$ ' and ' $B$ ' is shown in Tables 3 and 4.

Reservoir 'A' occurs (from base to top) at depth of (7878.01-7500.02ft) in well-048, (9225.41-8875.42ft) in well-042, (9125.32-8750.43ft) in well-026 and (8224.53-7800.32ft) in well-032. The petrophysical parameters for reservoir ' $A$ ' is shown in Table 3. The net sand thickness for reservoir ' $A$ ' across Well-048, 042,026 and 032 are $369.32,341.42,367.31$ and $412.23 \mathrm{ft}$ and Net to gross of $0.976,0.974,0.979$ and 0.969 respectively (Table 3 ). Porosity values obtained were rated very good to excellent, while permeability values were rated excellent based on Rider, (1996) criteria. Also reservoir 'B' occurs (from base to top) at depth of (8375.22 - 8424.53 ft) in well-048, (10037.31$10187.64 \mathrm{ft})$ in well-042, (10024.52 - 10200.12ft) in well-026 and (8975.32 - 9250.43ft) in well-032. With thicknesses of about $50.34 \mathrm{ft}$ in well-048, $150.62 \mathrm{ft}$ in well $042,175.23 \mathrm{ft}$ in well-026 and $274.53 \mathrm{ft}$ in well032 respectively (Table 4 ). Porosity values obtained in this reservoir were rated very good while permeability values were rated excellent based on Rider, (1996) criteria. The low average values of water saturation obtained for both reservoirs implies that the reservoir will produce water-free hydrocarbon at irreducible water saturation (Udegbunam, 1998) and attest to excellent reservoir quality in the field. After petrophysical values were evaluated for reservoirs ' $A$ ' and 'B', well log (gamma ray $\log$ ) from well-026 was integrated with seismic facies, to obtain a direct correlation between seismic facies type and lithology, to infer possible depositional environment from the log response. Three seismic facies were identified within the 3D seismic profile which are the upper 'unit A' characterised by sub-parallel and low amplitude discontinuous facies, the central 'unit B' containing highly faulted parallel and low to high amplitude discontinuous facies and the lower 'unit C' dominated by chaotic facies. It was observed that most of the major faults mapped in the field cuts across 'unit B' seismic facies and terminated on 'unit $\mathrm{C}$ '. In table 5 below, 'unit B' seismic facies was assigned a unique two-way time at top of reservoirs 'A', 'B', 'C' and 'D' and was mapped on the seismic grid. Gamma ray log shape from well-026 for reservoirs ' $A$ ', ' $B$ ', ' $C$ ' and ' $D$ ' were used to infer on possible environment of deposition of 'unit B' seismic facies across the various reservoirs.

\begin{tabular}{|c|c|c|c|c|c|}
\hline $\begin{array}{l}\text { Seismic } \\
\text { Facies }\end{array}$ & TWT(ms) & $\begin{array}{l}\text { GR log } \\
\text { (well-026) }\end{array}$ & Depth(ft) & Log Response & $\begin{array}{l}\text { GR- Inferred environment } \\
\text { of deposition }\end{array}$ \\
\hline Unit B & $\begin{array}{l}\text { 'A' top= } \\
-2227.76\end{array}$ & & $\begin{array}{c}\text { Top }=8750.43 \\
\text { Base }=9125.32\end{array}$ & $\begin{array}{l}\text { Serrated cylindrical } \\
\text { (blocky) }\end{array}$ & $\begin{array}{l}\text { Tidal channel, mouth bar, } \\
\text { shoreface }\end{array}$ \\
\hline Unit B & $\begin{array}{l}\text { 'B' top= } \\
-2475.09\end{array}$ & & $\begin{array}{l}\text { Top }=10024.52 \\
\text { Base }=10200.12\end{array}$ & $\begin{array}{l}\text { Serrated } \\
\text { Funnel/blocky shape }\end{array}$ & Tidal channel fill, barrier bar \\
\hline Unit B & $\begin{array}{l}\text { ' } C \text { ' top }= \\
-2516.98\end{array}$ & & $\begin{array}{l}\text { Top }=10450.47 \\
\text { Base }=10700.23\end{array}$ & $\begin{array}{l}\text { Serrated funnel shape } \\
\text { and coarsening } \\
\text { upward }\end{array}$ & Fluvial channels \\
\hline Unit B & $\begin{array}{l}\text { 'D' top= } \\
-2697.25\end{array}$ & & $\begin{array}{l}\text { Top }=11075.27 \\
\text { Base }=11188.22\end{array}$ & $\begin{array}{l}\text { Serrated funnel shape } \\
\text { and coarsening } \\
\text { upward }\end{array}$ & Delta front \\
\hline
\end{tabular}

Finally, Isochore maps which are particularly useful in analysing the geological history of an area was computed for horizons ' $A$ ' and ' $B$ ' (figures $7 \mathrm{a \& b}$ ). Horizon ' $A$ ' has relatively thick isochore (figure $7 \mathrm{a}$ ) with contour lines interval of $200 \mathrm{ft}$ to about $2600 \mathrm{ft}$ (from scale in figure 7a) which covers the other wells in the field. This pattern suggests that increased tectonic activities happened during deposition of reservpir ' $A$ ' and is an indication of a synrift deposit. Isochore map of reservoir ' $C$ ' has equal contour lines interval of $20 \mathrm{ft}$ to about $300 \mathrm{ft}$ (see scale of figure $7 \mathrm{~b}$ ).
This trend suggests that horizon ' $\mathrm{B}$ ' represents moderate sediment supply and low accommodation space, which allows the sediments to building out and creates progradational pattern during episodes of sea level fall associated with regressive events (Dodo, 2013).

Conclusion: This study have applied 3D seismic sections with well logs to delineate the structural style and trend of subsurface geological strcututres within the studied horizons to delineate hydrocarbon 
entrapment structures in the study area. Petrophysical parameters of the delineated reservoirs within four wells (Well-026, Well-032, Well-042 and Well-048) were also analysed.

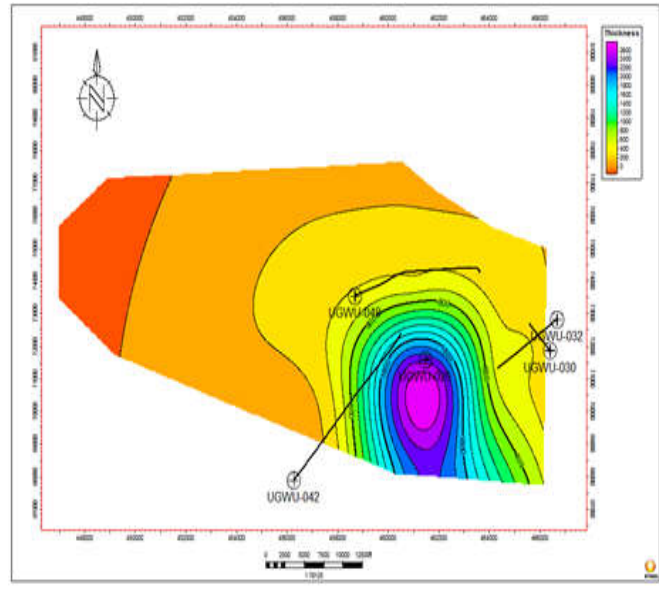

Fig 7a: Isochore map of horizon 'A' (E-W direction)

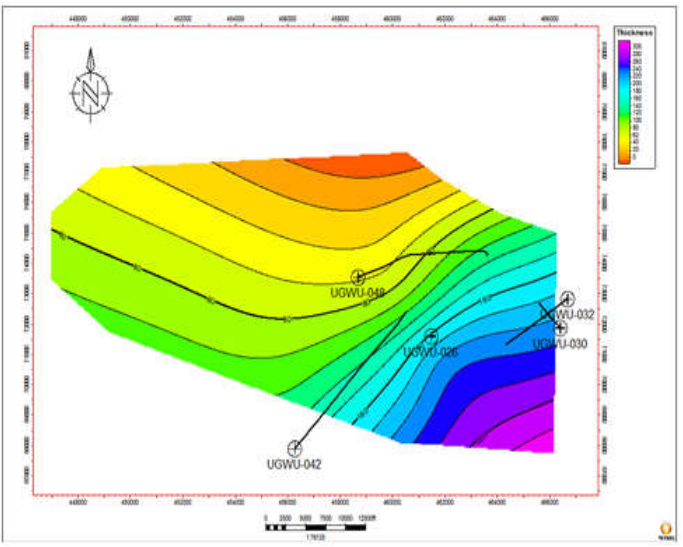

Fig 7b: Isochore map of horizon 'B' (E-W direction)

Time-depth maps, root mean square and variance attributes maps produced for reservoirs ' $A$ ' and ' $B$ ' across the four wells to delineate structural controls in the field which shows normal faults and rollover sturctures as the principal structural features in the field which depicts a typical tectonic setting of the Niger Delta basin. Results of petrophysical parameters of the studied reservoirs indicate that the reservoirs have a good prospect for hydrocarbon production.

Acknowledgement: We wish to express our gratitude to Shell Petroleum Development Company (SPDC) Port Harcourt for providing the data used for this study and to the Department of Geology, University of Port Harcourt, Nigeria for the use of her workstation platform and computing facilities.

\section{REFRENCES}

Adeoti, L; Igiri, T; Adekunle, A; Bello, MA (2014). Structural Style and Reservoir Distribution in Deep-water Niger Delta: A case study of "Nanny Field”. British J. Appl. Sci. Tech. 4(9): P. 13751391.

Alao, PA; Olabode, SO; Opeloye, SA (2013). Integration of seismic and Petrophysics to Characterize Reservoirs in "ALA" Oil Field, Niger Delta. The Sci. World J. Hindawi Publishing Corporation.

Ajisafe, YC; Ako, BD (2013). 3-D Seismic Attributes for Reservoir Characterization of "Y" Field Niger Delta. IOSR J. Appl. Geo. Geophy. 1, P. 23-31.

Archie, GE (1942). The electrical resistivity log as an aid in determining some reservoir characteristics. J. Pet. Tech. 5: P. 54- 62.

Asquith, G; Daniel K (2003). Basic Well Log Analysis. AAPG Methods in Exploration Series, No. 16. The American Association of Geologists Petroleum Geologists: Tulsa, OK. P. 137-142.

Ayolabi, EA; Adigun, AO (2013). The Use of Seismic Attributes to Enhance Structural Interpretation of Z-Field, Onshore Niger Delta. Published by Canadian Center of Sci. Edu; Earth Sci. Research; Vol. 2, No. 2.

Bahorich, MS; Farmer, SL (1995). 3D seismic coherency for faults and stratigraphic features: The Leading Edge, 14, P. 1053-1058.

Dodo, P (2013). Detailed reservoir study of the Lower Jurassic Tilje Formation around the Noatun and Linnorm Discoveries, HaltenTerrace, Norwegian Sea; Petroleum Geosciences Engineering, The University of Stavanger p. 62-64.

Etu-Effeotor, JO (1997). Fundamentals of Petroleum Geology. Department of Geological Sciences, University of Port-Harcourt, Rivers State, Nigeria. P. 23-65.

Eze, S; Orji, OM; Nnorom, SL; Ubogun, K (2019). Model Based Inversion of Acoustic impedance from Seismic trace for Lithofacies Differentiation: An Application in XY Field Offshore Niger Delta; Published in J. of Appl. Sci. Environ. Manage..23(9); P. 1677-1684.

Hansen, TM; Mosegaard, K; Pedersen-Tatalovic, R; Uldall, A; Jacobsen, NL (2008). Attribute-guided 
well-log interpolation applied to low-frequency impedance estimation. Geophysics. 73(6).: 83-95

Hart, BS; Pearson, RA; Rawling, GC (1997). 3D seismic horizon-based approaches to fractureswarm sweet spot definition in tight-gas reservoirs: The Leading Edge, 21, 28-35.

Karbalaali, H; Shadizadeh, SR; Ali, R (2013). Delineating hydrocarbon bearing zones using Elastic Impedance Inversion; A persian Gulf example. Iranian. J. Oil and Gas science and technology. 2 (2): P. 8-19.

Larionov, VV (1969). Borehole Radiometry: Moscow, U.S.S.R., Nedra.

Opara, AI (2010). Prospectivity Evaluation of "Usso" Field, Onshore Niger Delta Basin, Using 3-D Seismic and Well Log Data. Petroleum \& Coal 52 (4) P. 307-315.

Owolabi, A; Obot, AU (2001). Quality of groundwater in the Coastal plain Sands Aquifer of the Akwa Ibom State, Nigeria. J. Afri. Earth Sci. 27.2. 259275.

Peter and Amandeep (2013). Effective Fault Interpretation using 3-D Software Technology and Fault Displacement Analysis: $10^{\text {th }}$ Biennial International Conference \& Exposition india. P. 59.
Rider, (1996). The geological interpretation of well logs, $2^{\text {nd }}$ edition, Gulf Publishing Company. Houston, p. 230

Sanuade, OA; Akanji AO; Olaojo AA; Oyeyemi KD (2018). Seismic interpretation and petrophysical evaluation of $\mathrm{SH}$ field, Niger Delta. J. Petrol Explor Prod Technol 8: P. 51-60.

Tearpock, DJ Bischke, RE (2003). Applied subsurface geological mapping with Structural methods $\left(2^{\text {nd }}\right.$ edition) New York, Printice-Hall, P. 822.

Telford, WM;Geldart, LP; Sheriff, RE; Keys, DA(1976). Applied Geophyscis, Cambridge University Press, $3^{\text {rd }}$ Edition. p. 769.

Udegbunam, ; Amaefule, JO (1998). An Improved Technique fo Modeling Initial Reservoir Hydrocarbon Saturation Distributions. J. Pet. Sci. Engi., 21, 143-158.

Ukaigwe, NF (2000). A first course in Seismic exploration, Eddy-Joe publishers, Nigeria Ughelli, Port Harcourt. $2^{\text {nd }}$ ed: 85-86 \& P. 367372. 